
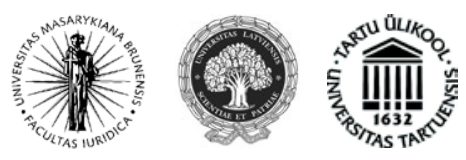

\title{
AR LIETUVOS RESPUBLIKOS RYŠIŲ REGULIAVIMO TARNYBA YRA PRIPAŽINTINA TEISMU PAGAL SESV 267 STRAIPSNĮ?
}

\author{
Eglè Kybartienè \\ Mykolo Romerio universiteto Teisès fakulteto \\ Tarptautinès ir Europos Sajungos teisès institutas \\ Ateities g. 20, LT-08303 Vilnius, Lietuva \\ Telefonas (+370 5) 2714669 \\ Elektroninis paštas egler@mruni.eu
}

Pateikta 2013 m. rugsejo 26 d., parengta spausdinti 2014 m. sausio 4 d.

doi:10.13165/JUR-13-20-4-08

\section{Ivadas}

Europos Sajungos Teisingumo Teismas (toliau - ESTT, Teismas) aiškiai nurodè, kad jis sprendžia, ar institucija yra „teismas“ pagal SESV 267 straipsni, ir kad institucijos nacionalinèje teisèje pripažinimas „teismu“ nèra galutinis. ESTT beveik penkis dešimtmečius savo sprendimuose kūrè ịvairių veiksnių, požymių ir kriterijų visumą, ị kurią reiktų atsižvelgti nustatant, ar institucija yra „teismas“.

Teismo praktikos analize atskleidžia, kad Teismas buvo labai lankstus savo aiškinimuose, kas yra „teismas“ pagal SESV 267 straipni, ir prièmé prašymų iš pramonès tribunolų, tam tikrų profesinių įstaigų ir kitų kvaziteisminių institucijų.

Lietuvos Respublika (toliau ir LR) skaičiuoja devintus narystės Europos Sajungoje metus. Akivaizdu, kad LR teismai, esantys sudedamaja ES teisminès sistemos dalimi, kasdienėje veikloje susiduria su jos teisès taikymu. Su ES teisès taikymu susiduria ir kitos institucijos, kurios sprendžia teisinius ginčus. Per šiuos narystės metus nacionaliniams teismams ir kitoms institucijoms ne tik prireikẻ taikyti ES teisės nuostatas, tačiau 
jie yra ịgyvendinę ir SESV 267 straipsnyje įtvirtintą teisę (ir pareigą) kreiptis dèl prejudicinio sprendimo.

Taigi, aktualu išanalizuoti kriterijus, apibūdinančius institucijas, galinčias tapti prejudicinio sprendimo procedūros subjektais bei įvertinti atitinkamos Lietuvos institucijos galimybes pasinaudoti SESV 267 straipsnyje numatyta procedūra. Lietuvos institicijų, kitų nei teismai, galimybẻ kreiptis prejudicinio sprendimo mažai tyrinètos. Deimilè Prapiestyte savo disertacijoje „Prejudicinio sprendimo prièmimo Europos Sajungos Teisingumo Teisme proceso aiškumas kaip vienodo Europos Sajungos teisès aiškinimo ir taikymo garantija"1 palietė kriterijus, apibūdinančius institucijas kaip teismą pagal SESV 267 straipsni, o Lietuvos Respublikos ryšių reguliavimo tarnybos (toliau - Ryšių reguliavimo tarnybos) teisinį statusą, jo vietą valstybinio administravimo institucijų sistemoje savo disertacijoje „Nepriklausomos reguliavimo institucijos valstybinio administravimo institucijų sistemoje“" aptarè Ieva Deviatnikovaitè ${ }^{2}$. Todèl autore pasirinko paliesti Lietuvoje visai nenagrinètą temą ir ịvertinti Ryšių reguliavimo tarnybos galimybes pasinaudoti SESV 267 straipsnyje numatyta procedūra. Išsamios analizès svarbą pagrindžia ir tai, kad ị ESTT dèl prejudicinio sprendimo prièmimo kreipèsi viena iš Lietuvos institucijų ${ }^{3}$, kuri pagal vidaus teisę nèra pripažistama teismu, o Teismas prièmè nagrinèti pateiktą prašymą dèl prejudicinio sprendimo prièmimo. Todèl tokia analizè turètų padèti kitoms Lietuvos institucijoms sprendžiant, ar jos turi teisę kreiptis dèl prejudicinio sprendimo.

Tyrimo objektas. Ryšių reguliavimo tarnybos atitiktis teismo sampratai pagal SESV 267 straipsnị.

Tyrimo tikslas. Atskleisti kriterijus, apibūdinančius institucijas, galinčias tapti prejudicinio sprendimo procedūros subjektais, bei Ryšių reguliavimo tarnybos galimybes pasinaudoti SESV 267 straipsnio numatyta procedūra.

Tyrimo metodai. Lyginamasis, analizès, loginis, apibendrinimo.

\section{Teisè kreiptis prejudicinio sprendimo: izžanginès pastabos}

Tam, kad ESTT priimtų prejudicinị sprendimą iš institucijos, turi būti ịgyvendintos 3 sąlygos. Pirma, besikreipianti institucija ESTT turi būti įvardijama kaip „teismas“ pagal SESV 267 straipsni $i^{4}$. Antra, besikreipianti institucija turi atitikti SESV 267

1 Prapiestytè, D. Prejudicinio sprendimo prièmimo Europos Sajungos Teisingumo Teisme proceso aiškumas kaip vienodo Europos Sajungos teisés aiškinimo ir taikymo garantija. Daktaro disertacija. Socialiniai mokslai (teisè). Vilnius: Vilniaus universitetas, 2012.

2 Deviatnikovaitè, I. Nepriklausomos reguliavimo institucijos valstybinio administravimo instituciju sistemoje. Daktaro disertacija. Socialiniai mokslai (teisè). Vilnius: Mykolo Romerio universitetas, 2012.

3 Byla C-385/09 Nidera Handelscompagnie [2010] ECR I-10385. Šioje byloje buvo nagrinèjamas Mokestinių ginčų komisijos prie Lietuvos Respublikos Vyriausybės pateiktas prašymas priimti prejudicini sprendimą. ES TT, išanalizavęs šios institucijos statusą pagal jurisprudencijoje suformuotus kriterijus, pateiktą prašymą prièmé, taip pripažindamas minètą Lietuvos instituciją teismu pagal SESV 267 straipsnį.

4 Žr., pvz., bylą C-516/99 Walter Schmid [2002] ECR I-4573 ir bylą C-259/04 Elizabeth FLorence Emanuel v. Continental Shelf [2006] ECR I-3089. 
straipsnyje nustatytą ,valstybés nare s“ teismo sąlygą ${ }^{5}$. Trečia, prejudicinis sprendimas turi būti susijęs su ES teisès aiškinimu arba galiojimu, prejudicinis sprendimas turi būti esminis besikreipiančiai institucijai sprendžiant bylą ir ESTT sprendimas turi būti privalomas besikreipiančiai institucijai ${ }^{6}$.

Šios 3 sąlygos yra taikomos kiekvienai institucijai, besikreipiančiai prejudicinio sprendimo. Dèl ribotos darbo apimties antroji ir trečioji sąlygos plačiau nagrinèjamos nebus.

Daugelyje bylų atsakymas ì klausimą, ar institucija yra „teismas“, yra akivaizdus, tačiau tam tikrais atvejais ESTT turi nustatyti institucijos statusą pagal SESV 267 straipsnic.

Teismo praktika šiuo klausimu yra labai nenuosekli ir apskritai neaiški ${ }^{7}$. Dažnai skirtumas tarp generalinių advokatų pasiūlytų išvadų ir Teismo sprendimų iliustruoja teisini ,valstybės narès teismo“ sąvokos neapibrèžtumą.

Atsižvelgiant ị acquis communautaire terminologijos specifiką, nebuvo galima pavesti valstybėms narėms nustatyti, koks teismas ar teisminè institucija turi „teismo“ statusą, nes kiekvienoje iš valstybių narių yra skirtingos teisminès institucijos bei skiriasi jų funkcijos. Paprastai valstybėse narėse egzistuoja bendrosios kompetencijos teismai, tačiau, be jų, yra ir specializuoti teismai ir/arba institucijos, turinčios specialiają kompetenciją. Kiekvienos valstybès narès vidaus teisinejje sistemoje yra teismų arba kitų ginčus sprendžiančių institucijų, turinčių skirtingą kompetenciją: vieni teikia nuomones, antri priima sprendimus, treti turi „mišrią kompetenciją“ (kartais veikia kaip viešojo administravimo institucija, o kartais kaip teismas). Jei besikreipiančioji i ETT (dabar ESTT - autorés pastaba) teisminès institucijos ar teismo statuso tikrinimo užduotis būtų pavesta valstybei narei, atsirastų rizika, kad ji gali suklysti. Tam tikras teismas ar ginčus sprendžianti institucija dèl padarytos „,vertinimo“ klaidos nepagrịstai prarastų teisę kreiptis dèl preliminaraus nutarimo (prejudicinio sprendimo - autorés pastaba) arba nepagrịstai tokią teisę igytų ${ }^{8}$.

Nuo 1961 m., kai buvo pateiktas pirmasis prejudicinio sprendimo prašymas, iki 1969 m. prašymų skaičius augo lètai - per visą ši laikotarpi pateikta vos 75 prašymai. Vèliau pastebimas spartus augimas, ypač tai būdinga 1990-1998 m., per ši laikotarpi pateiktų prašymų skaičius išaugo beveik 100 proc. ${ }^{9}$ Vèliau pateiktų prašymų skaičius augo tolygiai, tačiau nuolat. Beje, prašymų didèjimo šuolių negalima tiesiogiai sieti su

5 Žr. bylą C-321/97 Andersson and Wåkerås-Andersson [1999] ECR I-3551, paras 25, 27 ir 30 (tiek ESTT, tiek visos šalys ịtrauktos ị bylą, pripažino, kad tik „valstybès narès teismas“ gali pateikti prašymą).

6 Žr. bylą C-309/96 Daniele Annibaldi v. Sindaco del Comune di Guidonia and Prezidente Regione Lazio [1997] ECR I- 7493 ir bylą 244/80 Pasquale Foglia v. Mariella Novello [1981] ECR 3045, para 18.

7 Brown, L. Neville; Kennedy, T. The Court of Justice of the European Communities. London: Sweet \& Maxwell , 1994, p. 209-213; Bergères, M. Ch. Contentieux communautaire. Ed. Presses Universitaires de France, 2nd. Ed, p. 247-248.

8 Norkus, R.; Prapiestytè, D.; Valančius, V. Procesas Europos Bendriju Teisingumo Teisme: preliminarus nutarimas. Vilnius: Vİ Teisinès informacijos centras, 2004, p. 130-131.

9 Teisingumo Teismo $2012 \mathrm{~m}$. metinis pranešimas [interaktyvus]. Liuksemburgas, 2012 [žiūrèta 2013-0909]. <http://curia.europa.eu/jcms/upload/docs/application/pdf/201304/192685_2012_6020_cdj_ra_2012_en_ proof_01.pdf $>$. 
ES plètra. Pavyzdžiui, 1995 m. prie ES prisijungus Austrijai, Švedijai ir Suomijai, šių šalių įtaka bendram pateiktų prašymų augimui labai nežymi. Tą pati galima pasakyti ir apie 2004 m., kai prie ES prisijungè nemažas skaičius naujų šalių, tačiau pateiktų prejudicinių sprendimų skaičių tai veikè nežymiai: $2003 \mathrm{~m}$. buvo pateikta 210 prejudicinio sprendimo prašymų, 2004 m. - 249, 2005 m. - 221. 2005 m. iš dešimties naujų narių i ESTT su prejudicinio sprendimo prašymais kreipèsi tik Čekijos Respublika, Vengrija ir Lenkija, pateikdamos penkis paklausimus, o tai sudare tik daugiau nei 2 procentus Teismo krūvio ${ }^{10}$. Žinoma, naujoms narėms perpratus Bendrijos teisinę sistemą bylų skaičius auga.

Ryškus šuolis pastebimas 2010 m., kai per metus pateiktų prejudicinių sprendimų prašymų skaičius išaugo nuo 302 iki 385 (28 proc.), o $2011 \mathrm{~m}$. net iki 423 prašymų, 2012 m. pateikti 404 prašymai $^{11}$. Tai akivaizdus Lisabonos sutarties pokyčių rezultatas aiškiai apibrèžta nuostata, kad prašyti prejudicinio sprendimo gali visi nacionaliniai teismai, paskatino teismus teikti prašymus.

\section{2. „Teismo“ sąvoka pagal SESV 267 straipsni}

ES sutarties 19 straipsnyje ir SESV 267 straipsnyje minimi ,valstybės narès teismai“. Bet ką tai reiškia? Kurios instirucijos gali kreiptis prejudicinio sprendimo, o iš kurių ESTT prašymų nepriimtų? Tam būtina peržvelgti ESTT jurisprudenciją, nes Sutartys jokio apibrèžimo nepateikia.

Ankstyvoje Bendrijos egzistavimo stadijoje Teismas neturèjo aiškių kriterijų, kuriais galètų vadovautis sprendžiant, ar valstybès narès institucija yra „teismas“. Tiksliau, net iki 1966 m. Teismas nenustate šių labai reikalingų vertinimo ịrankių.

Pirmą kartą nuomonę, kas yra „nacionalinis teismas“, kokius kriterijus jis turi atitikti, ESTT pateike 1966 m. birželio 30 d. sprendime Vaassen-Goebbels ${ }^{12}$. Teismas išaiškino, kad „sąvoka „teismas“, nurodyta Sutarties 177 straipsnyje (dabar - SESV 267 straipsnis), tam tikromis aplinkybemis gali apimti ir institucijas, nepriskiriamas ịprastiniams teismams“. Kita vertus, pačios institucijos savęs vertinimas kaip teisminès institucijos savaime nereiškia, kad ji turi teisę kreiptis prejudicinio sprendimo ${ }^{13}$.

Kalbant apie tai, ko buvo pasiekta Vaassen-Göbbels byla, galima būtų teigti, kad dabar ESTT jau turejjo penkis kriterijus, kuriais galejo remtis nustatydamas, ar institucija gali būti laikoma ,teismu“, o būtent: ar institucija, įkurta teisès aktų pagrindu, ar ji yra nuolatinè, ar ji taiko teisès normas, ar jos jurisdikcija yra privaloma, ar jos procesas grindžiamas rungimosi principu. Taip pat reikètų pažymèti, kad po šio sprendimo ESTT vèlesnèse bylose nustatinèjo, ar šios sąlygos yra įvykdytos, šiuos kriterijus tobulino ir pridèjo kitų ${ }^{14}$. Pavyzdžiui, reikalavimas, kad institucija būtų nepriklausoma, buvo pa-

10 Ibid.

11 Ibid.

12 Byla 61/65 Vaasen-Göbbels [1966] ECR 261.

13 Byla 24/92 Corbiau v. Administration des Contributions [1993] ECR I-1277.

14 Generalinio advokato Ruiz-Jarabo Colomer nuomonè byloje C-17/00 De Coster [2001] ECR I-9445, para 17. 
minètas bylos Pretore di Salo ${ }^{15}$ sprendime ir besąlygiškai priimtas Corbiau byloje ${ }^{16}$. Atkreiptinas dèmesys, kad nepriklausomumo kriterijus, kuris yra svarbiausia teismo savybè, turejjo palaukti iki 1987 m., kol pasirodè ESTT sprendime.

Teismų praktika išliko nepakitusi dèl kai kurių reikalavimų, ypač tokių, ar institucija yra ịsteigta pagal ịstatymą, ar ji yra nuolatinè, ar ji taiko teisès normas. Tačiau kiti, kurie aiškiausiai apibrèžia teismą, pavyzdžiui, būtinas nepriklausomumo kriterijus, inter partes procedūra ar teisminio pobūdžio sprendimas, buvo interpretuojami ịvairiai ir kartais labai painiai.

Siekiant nustatyti, ar tam tikras nacionalinis teismas gali būti laikomas "teismu“ pagal SESV 267 straipsnį, reikia ịvertinti jo atitiktį paties ESTT savo jurisprudencijoje nustatytiems reikalavimams ir kriterijams. Kol nèra abstrakčios „teismo“ sąvokos 267 straipsnyje, vis dèlto galima iš Teismo praktikos išskirti tam tikrą skaičių kriterijų, kurie būtini nustatant, kurios institucijos gali kreiptis dèl prejudicinio sprendimo pagal šią nuostatą.

Nuo 1997 m. ESTT, priemęs sprendimą Dorsch Consult byloje ${ }^{17}$, pradejo vartoti formuluotę ,siekiant nustatyti, ar institucija, kuri kreipiasi dèl prejudicinio sprendimo, turi „teismo“ statusą pagal EB sutarties 234 straipsnị (dabar SESV 267 straipsnis - autorés pastaba), reikia vadovautis tokiais kriterijais, ,isteigta teisès aktais, nuolatine veikla, proceso metu sprendžiamas ginčas, taiko teisès aktus ir yra nepriklausoma“. Nors Teismas tiesiogiai nenurode, kad tai yra baigtinis kriterijų, leidžiančių nustatyti „teismo“ statusą, sąrašas, tačiau juo vèliau rèmèsi tiek pats Teismas, tiek Generaliniai advokatai ${ }^{18}$.

Tais atvejais, jei buvo nustatoma, kad besikreipianti institucija nèra „teismas“ pagal valstybės narès vidaus teisę, ESTT dar tikrindavo, ar ši institucija atitinka ir kitus kriterijus, parodančius ịgyvendinamų funkcijų pobūdį, tokius kaip, ar jos jurisdikcija yra privaloma, ar ji nagrinèja ginča , ar priima teisminio pobūdžio sprendima ${ }^{19}$.

Teismo praktika tiksliai neapibrèžia „teismo“ sąvokos pagal SESV 267 straipsnị, tačiau galima teigti, kad nors atrodo, kad yra tan tikri kirterijai, kurie atrodo labai svarbūs iš pirmo žvilgsnio, tačiau Teismas negrindžia savo sprendimų remdamasis tik tuo, ar institucija yra privati arba vieša, ar yra galimybė apskųsti sprendimą. Daug svarbesnis yra nacionalinių valdžios institucijų dalyvavimo laipsnis, nepriklausomumo ir nešališkumo lygis, taip pat ginčo pobūdis ir institucijos sprendimas.

Ar Lietuvos Respublikos ryšių reguliavimo tarnyba yra teismas SESV 267 straipsnio prasme?

Kiekvienoje ES valstybeje nareje, taip pat ir Lietuvoje, be teismų, yra įvairių valstybinių institucijų, kurios sprendžia teisinius ginčus. Viena tokių yra Ryšių reguliavimo tarnyba.

15 Byla 14/86 Pretore di Salò [1987] ECR 2545.

16 Byla C-24/92 Corbiau [1993] ECR I-1277.

17 Byla C-54/96 Dorsch Consult [1997] ECR I-4961.

18 Byla C-258/97 HI [1999] ECR I-1405 ir byla C-275/98 Unitron Scandinavia et 3-S [1999] ECR I-8291.

19 Byla 61/65 Vaassen - Goebbels [1966] ECR 261, byla 246/80 Broekmeulen [1981] ECR 2311; byla C-54/96 Dorsch Consult [1997] ECR I-4961; byla C-103/97 Josef Köllensperger GmbH\&Co. KG and Atzwanger AG v. Gemeindeverband Bezirkskrankenhaus Schwaz [1999] ECR I-551; byla C-407/98 Abrahamsson ir Anderson [2000] ECR I-5539. 
Vertinant šią instituciją pagal visus anksčiau išvardintus kriterijus iš jų galima išskirti institucijos ịsteigimą, jos veiklos vykdymą vadovaujantis teisès aktais ir juose nustatytą tvarką bei institucijos tęstinumą. Ši institucija valstybinio lygmens, taigi įsteigta nuolatinei veiklai ịstatymų nustatyta tvarka ir visus šiuos tris kriterijus atitinka. Dèl ribotos darbo apimties detaliai šie kriterijai nebus nagrinèjami, o nurodomi tik konkretūs teisès aktai, kuriais vadovaujantis institucija įkurta bei vykdo veiklą. Taigi, toliau vertinant, ar ši institucija būtų pripažinta „teismu“ pagal 267 straipsnį, bus nagrinèjami kiekvienas atskirai bei grupès šiu kriterijų:

1. Institucijos nepriklausomumas;

2. Institucijos jurisdikcijos ir sprendimų privalomumas;

3. Ginčų nagrinėjimas institucijoje ginčo teisenos tvarka;

4. Prejudicinio sprendimo besikreipiančios institucijos nariai turi turèti teisinị išsilavinimą.

Ryšių reguliavimo tarnybos nuolatinè institucija buvo ịkurta vadovaujantis Lietuvos Respublikos telekomunikacijų įstatymu ${ }^{20}$, jos galios, veikla ir igaliojimai reglamentuojami Lietuvos Respublikos elektroninių ryšių įstatymo ${ }^{21}$ bei Lietuvos Respublikos pašto įstatymo ${ }^{22}$. Vyriausybès $2000 \mathrm{~m}$. liepos $10 \mathrm{~d}$. nutarimu Nr. 798 buvo pavirtinti RRT nuostatai, jų 1 punkte nustatyta, kad RRT yra savarankiška Vyriausybès įstaiga. Tačiau Vyriausybès 2004 m. rugpjūčio 19 d. nutarimu Nr. 1029 patvirtintuose nuostatuose Ryšių reguliavimo tarnyba jau buvo ịtvirtinta kaip savarankiška valstybės įstaiga. Kaip nustatyta Ryšių reguliavimo tarnybos nuostatų $u^{23} 1$ straipsnio 2 punkte: „Savo veikloje Tarnyba vadovaujasi Lietuvos Respublikos Konstituci$\mathrm{ja}^{24}$, Europos Sajungos teisès aktais, Lietuvos Respublikos tarptautinėmis sutartimis, Lietuvos Respublikos civiliniu kodeksu ${ }^{25}$, Lietuvos Respublikos įstatymais, kitais Lietuvos Respublikos Seimo priimtais teisès aktais, Respublikos Prezidento dekretais, Lietuvos Respublikos Vyriausybės nutarimais, šiais nuostatais ir kitais teisès aktais“. Elektroninių ryšiu įstatymo 9 straipsnyje nustatyta ${ }^{26}$, kad Ryšių reguliavimo tarnyba: 1) prižiūri ir ịgyvendina šio İstatymo ir jo ịgyvendinamujų teisès aktų nuostatas; 2 ) rengia ir tvirtina reikalavimus aparatūrai ir įrenginiams ir jų naudojimo sąlygas, teisès aktų nustatytais atvejais išduoda leidimus naudoti aparatūrą ir ịrenginius, ịvežti ir naudoti radijo stebėsenos ir radijo ryšio slopinimo įrenginius; 3) rengia ir tvirtina Nacionalinę radijo dažnių paskirstymo lentelę, kartu su Lietuvos radijo ir televizijos komisija rengia ir tvirtina radijo dažnių skyrimo radijo ir televizijos programoms transliuoti ir siųsti planą; 4) bendradarbiauja su užsienio valstybių elektroninių ryšių veiklos reguliavimo

20 Lietuvos Respublikos telekomunikacijų įstatymas. Valstybès žinios. 1998, Nr. 56-1548, 3 straipsnio 1 dalies 2 punktas.

21 Lietuvos Respublikos elektroninių ryšių ịstatymas. Valstybès žinios. 2004, Nr. 69-2382, 4 straipsnio 2 dalis.

22 Lietuvos Respublikos pašto įstatymas. Valstybès žinios. 1999, Nr. 36-1070; 2012, Nr. 135-6867.

23 Lietuvos Respublikos Vyriausybès nutarimas dèl Lietuvos Respublikos ryšių reguliavimo tarnybos nuostatų patvirtinimo. Valstybès žinios. 2004, Nr. 131-4734.

24 Lietuvos Respublikos Konstitucija. Valstybès žinios. 1992, Nr. 31-953.

25 Lietuvos Respublikos civiliniu kodeksas. Valstybès žinios. 2000, Nr. 74-2262.

26 Lietuvos Respublikos elektroninių ryšiu įstatymas, supra note 21. 
institucijomis, pagal kompetenciją dalyvauja tarptautinių organizacijų ir Europos Sąjungos institucijų, komitetų bei grupių, kurių veikla susijusi su elektroniniais ryšiais (telekomunikacijomis), radijo ryšio įrenginiais ir galiniais įrenginiais, elektromagnetiniu suderinamumu ir (arba) radijo spektro valdymu, viešujų ryšių tinklų ir (arba) viešujų elektroninių ryšių paslaugų saugumu, veikloje, taip pat Europos elektroninių ryšių reguliuotojų institucijos veikloje, reikiamais atvejais skiria ekspertus, kurie dalyvautų atitinkamuose komitetuose ir grupėse, atlieka tarptautinị radijo dažnių (kanalų) ir orbitinių išteklių koordinavimą bei tarptautinę radijo ryšio stočių (radijo dažnių) ir orbitinių išteklių apsaugą; 5) rengia ir teikia Vyriausybei ar jos ịgaliotai institucijai pasiūlymus dèl elektroninių ryšių veiklos politikos; 6) rengia ir teikia Vyriausybei pasiūlymus dẻl universaliujų paslaugų kainų aukščiausios ribos, rengia ir teikia Vyriausybei tvirtinti universaliujų paslaugų teikimo nuostolių kompensavimo taisykles; 7) nustato universaliujuc paslaugų teikimo taisykles, ịpareigojimus nepaskirtiems teikti universaliąsias paslaugas ūkio subjektams, kad būtų galima tinkamai teikti universaliąsias paslaugas; 8) Vyriausybės nustatyta tvarka kaupia ir saugo informaciją apie tai, kokius techninių ivvykių duomenis apie elektroninius ryšius fiksuoja ir saugo ūkio subjektai, teikiantys elektroninių ryšių tinklus ir (arba) paslaugas; 9) vykdo nacionalinio elektroninių ryšių tinklų ir informacijos saugumo incidentų tyrimo padalinio veiklą; 10) yra atsakinga už tiesiogiai taikomų Europos Sajungos teisès aktų, reglamentuojančių šio įstatymo reguliavimo dalyką, nuostatų vykdymo priežiūrą.

Nepriklausomumas. Kalbant apie šios institucijos nepriklausomumą, svarbu atkreipti dèmesi i ES teisę, kuri pabrèžia nacionalinių reguliavimo institucijų nepriklausomumo būtinumą. Europos Parlamento ir Tarybos direktyvoje 2009/140/EB ${ }^{27}$ nurodyta, kad „Siekiant užtikrinti veiksmingesnį reguliavimo sistemos taikymą, nacionalinių reguliavimo institucijų autoritetą ir pagerinti jų sprendimų nuspejjamumą, turètų būti stiprinamas šių institucijų nepriklausomumas. Todèl nacionalinèje teisèje turètų būti speciali nuostata, kuria būtų užtikrinta, jog ị nacionalinès reguliavimo institucijos atliekamas užduotis nebūtų kišamasi iš išorès ar nebūtų daromas politinis spaudimas, dẻl kurio būtų pakenkta institucijos sprendimų nepriklausomumui. Dėl išorès poveikio nacionalinis įstatymų leidžiamasis organas nėra tinkamas pagal šią reguliavimo sistemą veikti kaip reguliavimo institucija. Todèl turètų būti iš anksto nustatytos nacionalinès reguliavimo institucijos vadovo atleidimo taisyklès, kad nekiltų jokių pagrịstų abejonių dèl jos neutralumo ar dèl išorès veiksnių poveikio šiai institucijai. Svarbu, kad nacionalinès reguliavimo institucijos, atsakingos už ex ante rinkos reguliavimą, turètų nuosavą biudžetą." Savo disertacijoje „Nepriklausomos reguliavimo institucijos valstybinio administravimo institucijų sistemoje“" I. Deviatnikovaitė nurodo, kad atsižvelgiant ị ES nepriklausomumo reikalavimų, keliamą nacionalinėms reguliavimo institucijoms, mechanizmą, įžvelgiamas politinio nepriklausomumo įtvirtinimas. Ji galima išskaidyti i

27 Europos Parlamento ir Tarybos 2009 m. lapkričio 25 d direktyva 2009/140/EB, iš dalies keičianti Direktyvą 2002/21/EB dèl elektroninių ryšių tinklų ir paslaugų bendrosios reguliavimo sistemos, Direktyvą 2002/19/EB dèl elektroninių ryšių tinklų ir susijusių priemonių sujungimo ir prieigos prie jų ir Direktyvą 2002/20/EB dèl elektroninių ryšių tinklų ir paslaugų leidimo. [2009] OL, L 337/37. 
keletą struktūrinių elementų - institucinį, asmeninị arba personalinị, finansinį nepriklausomumą ${ }^{28}$.

Institucinis Ryšiu reguliavimo tarnybos nepriklausomumas itvirtinamas terminu „savarankiška“ institucija. Tai reiškia, kad jokios institucijos negali stabdyti, naikinti, veikti Ryšiu reguliavimo tarnyba sprendimų ${ }^{29}$. Ryšių reguliavimo tarnybai vadovauja direktorius, kuris skiriamas Lietuvos Respublikos Prezidento Ministro Pirmininko teiki$\mathrm{mu}^{30}$. Tarnybos veikla organizuojama vadovaujantis direktoriaus patvirtintais strateginiais planais, kurie sudaromi vadovaujantis ịstatymais ir derinami su Vyriausybės programa, Valstybès ilgalaikès raidos strategija ir kitais strateginio planavimo dokumentais. Šis planas skelbiamas Tarnybos internetiniame tinklalapyje, o jo vykdymą kontroliuoja direktorius. Direktoriaus atlyginimo nustatymas reguliuojamas Lietuvos Respublikos Valstybès politikų, teisèjų ir valstybės pareigūnų darbo apmokèjimo įstatymu ${ }^{31}$.

Personalinis Ryšiu reguliavimo tarnybos nepriklausomumas užtikrinamas vadovybès formavimo tvarka, kadencijos nustatymu, keliamais reikalavimais pretendentams, vadovybès veiklos ribojimu, atleidimo nesibaigus kadencijai nustatytomis sąlygomis ${ }^{32}$. Ryšių reguliavimo tarnybos direktorių 5 metams skiria Prezidentas Ministro Pirmininko teikimu. Taip pat svarbu, kad tiek Tarnybos veiklą reglamentuojančiame įstatyme ${ }^{33}$, tiek jo nuostatuose ${ }^{34}$ arškiai apibrèžtas atvejų, kuriais Lietuvos Respublikos Prezidentas gali iš pareigų atleisti Tarnybos direktorių ar tarybos narius, baigtinis sąrašas. Specifinių išsilavinimo kriterijų vadovui ịstatyme nèra nustatyta. Taigi tai paliekama Prezidento diskrecijai. Nėra nustatyta ir kiek kadencijų tas pats asmuo gali eiti direktoriaus pareigas, nenurodyti ir Ryšių reguliavimo tarnybos direktoriaus, jo pavaduotojų veiklos apribojimai. Būtina nurodyti ir tai, kad specialiose Ryšių reguliavimo tarnybos priimtose ginčų nagrinejimo taisyklèse nustatyta, kad ginčui nagrinèti skiriamas tarnyboje dirbantis valstybès tarnautojas ir kartu nustatoma, kad konkrečiam ginčui nagrinèti negali būti skiriamas toks tarnautojas, kuris nagrinėdamas ginçą gali patekti ị interesų konfliktą̧ Interesų konflikto apibrěžime priežastims, galinčioms jị sukelti, minẻtose taisyklėse pateikiama nuoroda ị Lietuvos Respublikos viešujų ir privačių interesų derinimo valstybinèje tarnyboje įstatymą ${ }^{36}$.

28 Deviatnikovaite, I., supra note 2, p. 146.

29 Ibid., p. 195.

30 Lietuvos Respublikos elektroninių ryšių ístatymas, supra note 21, 7 straipsnio1 dalis.

31 Lietuvos Respublikos Valstybès politikų, teisèjų ir valstybès pareigūnų darbo apmokejjimo įstatymas. Valstybès žinios. 2000, Nr. 75-2271.

32 Deviatnikovaite, I., supra note 2, p. 195.

33 Lietuvos Respublikos elektroninių ryšių įstatymas, supra note 21, 7 straipsnio 9 dalis.

34 Lietuvos Respublikos ryšių reguliavimo tarnybos nuostatai. Valstybès žinios. 2004, Nr. 131-4734, 21 punktas.

35 Lietuvos Respublikos ryšių reguliavimo tarnybos direktoriaus $2011 \mathrm{~m}$. spalio 21 d. ịsakymu Nr. 1V-1015 patvirtintos galutinių paslaugų gavejjų ginčų su elektroninių ryšių paslaugų tiekejjais ir ginčų tarp pašto ir(ar) pasiuntinių paslaugų tiekejų ir naudotojų nagrinèjimo taisyklès. Valstybès žinios. 2011, Nr. 1306176,28 ir 29 punktai.

36 Lietuvos Respublikos viešujų ir privačių interesų derinimo valstybinèje tarnyboje įstatymas. Valstybès žinios. 1997, Nr. 67-1659; 2000, Nr. 18-431. 
Kitas Ryšių reguliavimo tarnybos valdymo organas yra taryba, kuri sudaroma iš septynių narių, o jos pirmininkas yra direktorius. Tarybos narius taip pat skiria Lietuvos Respublikos Prezidentas Ministro Pirmininko teikimu, vieni nariai gali būti mokslininkai, kiti - įvairių ministerijų, tarnybų atstovai ${ }^{37}$, o jų darbas yra nemokamas. Tarybos veikla reguliuojama pačios tarybos priimamo darbo reglamento ${ }^{38}$. Taryba skiria direktoriaus pavaduotoją ir direktoriaus vienkartines priemokas ir paskatinimus, dèl jų posédžiaujant pats direktorius nebalsuoja ${ }^{39}$. Ryšių reguliavimo tarnybos vidaus darbo tvarką reguliuoja grynai pati tarnyba - kaip jau minèta, darbo reglamentą priima taryba, taip pat ji kartu su direktoriumi derina Tarnybos struktūrą ir padalinių nuostatus, pajamų ir išlaidų biudžeto tvirtinimą, o direktorius savo nuožiūra priima ir atleidžia asmenis, dirbančius pagal darbo sutartis, taip pat jis tvirtina tarybos pareigybių sąrašus ir aprašymus $^{40}$. Svarbu tai, kad pati Tarnybos taryba sprendžia dèl ginčų tarp ūkio subjektų sprendimo taisyklių bei tarpininkavimo ir (ar) taikinimo procedūrų taisyklių ${ }^{41}$. Tarnybos atskaitomybė taip pat sureguliuota Lietuvos Respublikos elektroninių ryšių ístatyme (6 straipsnio 4 dalyje) ir Ryšių reguliavimo tarnybos nuostatuose (18.10 punkte), kurie numato, kad bent vieną kartą per metus Tarnybos direktorius teikia Tarnybos veiklos ir finansinę rašytinę ataskaitą Tarnybos tarybai, Lietuvos Respublikos Seimui, Vyriausybei, taip pat ją skelbia viešai.

Direktyvose paminėta, jog nacionaliniam reguliavimo subjektui svarbu turèti nuosavą biudžetą, kurị galètų naudoti įdarbindamas reikiamą kvalifikuotų darbuotojų skaičių. Finansinis nepriklausomumas iš dalies užtikrintas tuo, kad Tarnyba finansuojama iš valstybės biudžeto ir atskiro Tarnybos biudžeto, kurị sudaro visos Tarnybos pajamos, gautos už teikiamas paslaugas ir atliekamus darbus ${ }^{42}$. Šie biudžetai apskaitomi atskirai vienas nuo kito. Viršplaninės Tarnybos pajamos $\mathfrak{i}$ atskirą Tarnybos biudžetą, taip pat nepanaudotos atskiro Tarnybos biudžeto lèšos einamaisiais finansiniais metais arba perkeltos ị kitus finansinius metus paliekamos Tarnybai ir gali būti naudojamos viršijant patvirtintas asignavimų sumas ${ }^{43}$.

Jurisdikcijos ir sprendimų privalomumas. Ryšių reguliavimo tarnybos privaloma išankstinè neteisminė ginčų nagrinėjimo jurisdikcija nustatyta Lietuvos Respublikos elektroninių ryšių įstatymo 28 straipsnio 1 dalyje. Be to, toje pačioje įstatymo normoje suformuluotas ir ịpareigojimas už ginčo sprendimą sumokèti ginčo nagrinejjimo mokestị, taip pat - reglamentuojamas ir ginčo šalių patirtų teisinių išlaidų atlyginimas, o nustatant jo tvarką daroma nuoroda ị Lietuvos Respublikos civilinio proceso kodeksą ${ }^{44}$. Taip

37 Lietuvos Respublikos Prezidento 2007 m. rugpjūčio 3 d. dekretas Nr. 1K-1077 „Dėl Ryšių reguliavimo tarnybos tarybos narių skyrimo“. Valstybès žinios. 2007, Nr. 88-3486.

38 Lietuvos Respublikos elektroninių ryšių ịstatymas, supra note 21,7 straipsnio 3 dalis.

39 Lietuvos Respublikos ryšių reguliavimo tarnybos nuostatai, supra note 34, 14 punktas.

40 Lietuvos Respublikos ryšių reguliavimo tarnybos nuostatai, supra note 34, 16-20 punktai.

41 Ibid., 20.10 punktas; Lietuvos Respublikos elektroninių ryšių įstatymas, supra note 21, 8 straipsnio 7 dalies 9 punktas.

42 Deviatnikovaitè, I., supra note 2, p. 195.

43 Lietuvos Respublikos ryšių reguliavimo tarnybos nuostatai, op cit., 24 ir 25 punktai.

44 Lietuvos Respublikos elektroninių ryšių įstatymas, op. cit., 28 straipsnio 3 dalis. 
pat imperatyviai reglamentuojamas ir priimto Ryšių reguliavimo tarnybos sprendimo dèl ginčo privalomumas - jis nustatytas Elektroninių ryšių ịstatymo 28 straipsnio 16 dalyje, o to pačio straipsnio 18 dalyje nustatyta jo apskundimo Vilniaus apygardos teismui tvarka. Be to, tarnybos priimtas sprendimas yra laikomas vykdomuoju dokumentu ir jo nevykdant geranoriškai jis gali būti vykdomas priverstine tvarka Lietuvos Respublikos civilinio proceso nustatyta tvarka ${ }^{45}$. Svarbu paminèti ir tai, kad pagal Lietuvos Respublikos civilinio proceso normas sprendimai atsisakyti priimti prašymą, palikti prašymą nenagrinètą, nutraukti ar sustabdyti ginčo nagrinèjimą gali užkirsti kelią tolesniam ginčo nagrinèjimui, o nagrinèjamo ginčo šalims Elektroninių ryšiu įstatymo 28 straipsnio 17 dalyje numatyta galimybè tokius Ryšių reguliavimo tarnybos priimtus procesinius sprendimus taip pat apskųsti Vilniaus apygardos teismui.

Ginčo nagrinẻjimo tvarka. Bendrosios ginčų tarp ūkio subjektų, teikiančių elektroninių ryšių tinklus ir (ar) paslaugas, nagrinèjimo taisyklès reglamentuojamos jau minètame Elektroninių ryšių įstatymo 28 straipsnyje. Jame nustatoma tiek jau aptarta kreipimosi ị instituciją neteisminè tvarka bei jurisdikcijos privalomumas, tiek pačio prašymo nagrinèti ginčą prièmimo tvarka (čia daroma nuoroda ị Lietuvos Respublikos civilinio proceso kodekso 115 straipsnio 1-4 dalių nuostatas), tiek atsisakymo priimti pareiškimą sąlygos, taip pat ginčo nagrinèjimo nutraukimo, sustabdymo atvejai, galimybė taikyti laikinąsias apsaugos priemones bei bendrosios ginčo dalyvių teisès: susipažinti su nagrinejjamo ginčo medžiaga, teikti įrodymus, paaiškinimus, samprotavimus ir argumentus, kitai šaliai jiems prieštarauti, taip pat gauti sprendimo nuorašus, sprendimus skųsti, atsisakyti prašymo nagrinèti ginčą ar toki prašymą kitai šaliai pripažinti, turèti savo atstovus $^{46}$. Bendra tvarka ginčai nagrinėjami rašytinio proceso būdu, tačiau yra sudaroma galimybė ir žodiniam nagrinejjimui, kurio metu ginčo šalių neatvykimas netrukdo Ryšių reguliavimo tarnybai priimti sprendimą (su tam tikromis išimtimis). Būtina pabrèžti ir tai, kad nepaisant to, kad daugelis procedūrinių klausimų reglamentuojami pateikiant nuorodas ị Lietuvos Respublikos civilinio proceso kodeksą, vis dèlto Tarnybos nagrinëjamų ginčų procedūra detalizuojama ir specialiose Ryšių reguliavimo tarnybos priimtose taisyklèse $\mathrm{e}^{47}$, kurios nustato prašymo nagrinèti ginčą formą, pateikimo tvarką, ginčo šalių teises ir pareigas, detalią ginčo nagrinèjimo procedūrą. Šiose taisyklèse pakartotinai nurodoma, kad ginčo šalys gali ne tik susipažinti su visa ginčo nagrinejjimo medžiaga, teikti Tarnybai ịrodymus, paaiškinimus, argumentus ir samprotavimus, prašymus, prieštarauti kitos šalies ar kitų suinteresuotų asmenų, dalyvaujančių nagrinejjant ginčą, prašymams, paaiškinimams, argumentams ir samprotavimams, gauti Tarnybos sprendimų, priimtų nagrinëjant ginčą, nuorašus, apskųsti Tarnybos sprendimus ir naudotis kitomis teisèmis, kurias suteikia Lietuvos Respublikos elektroninių ryšiu įstatymas, Lietuvos Respublikos pašto įstatymas bei šios Taisyklès, bet taip pat ir suteikia teisę nemokančioms valstybinès kalbos ginčo šalims naudotis vertejjo paslaugomis, taip

45 Ibid., 28 straipsnio 19 dalis.

46 Lietuvos Respublikos elektroninių ryšių ịstatymas, supra note 21, 28 straipsnio 11 dalis.

47 Lietuvos Respublikos ryšių reguliavimo tarnybos direktoriaus $2011 \mathrm{~m}$. spalio $21 \mathrm{~d}$. ịsakymu Nr. 1V-1015 patvirtintos galutinių paslaugų gavejjų ginčų su elektroninių ryšių paslaugų tiekejjais ir ginčų tarp pašto ir (ar) pasiuntinių paslaugų tiekẻjų ir naudotojų nagrinejjimo taisyklès, supra note 35. 
pat teisę keisti prašymo nagrinėti ginčą pagrindą arba dalyką, keisti reikalavimų apimtis, jų atsisakyti arba juos pripažinti bei ginčą užbaigti taikos sutartimi.

Kvalifikacija. Nei Ryšių reguliavimo tarnybos direktoriaus, nei tarybos narių kvalifikaciniai reikalavimai nėra aptariami, privalomos nuostatos, kad direktorius, jo pavaduotojas ar bet kuris narys turètų teisinị išsilavinimą, nėra.

\section{Apibendrinimas}

Bendrai Ryšių reguliavimo tarnybos veikla, struktūra, narių prièmimo, apmokèjimo ir atleidimo, vidaus tvarkos reikalavimai, veiklos vykdymas labai gerai ir pakankamai detaliai reglamentuotas tiek specialiu Elektroninių ryšių ịstatymu, tiek Ryšių reguliavimo tarnybos nuostatais, tiek specialiomis ginčų nagrinejjimo taisyklèmis. Svarbu, kad nepriklausomumo kriterijus užtikrinamas tiek asmeniniu, tiek instituciniu lygmeniu, kadangi minètuose teisès aktuose aiškiai aptarta valdymo organų narių prièmimo ir atleidimo tvarka, institucijos atskaitomybè nepriskirta tik vienai konkrečiai valdančiajai institucijai, bet yra vieša, be to, institucija nėra absoliučiai priklausoma nuo valstybès biudžeto, bet gali generuoti savo léšas. Vis dẻlto trūksta detalesnio valdančių institucijos organų narių asmeninio nepriklausomumą užtikrinančių finansinių garantijų, be to, neatlygintinas tarybos narių darbas vertintinas dvipusiškai - viena vertus, ne finansinis, bet profesinio tobulèjimo ir visuomeninio darbo, pilietiškumo akstinas atliekamų funkcijų nesiejant su finansiniu atlygiu atriboja tarybos narių priimamus sprendimus nuo materialaus įvertinimo ir taip galimai nutolina suinteresuotumą papildomu materialiniu paskatinimu, vis dèlto galimas ir atvirkštinis procesas - už atliekamas funkcijas adekvataus finansinio atlygio nebuvimas neužtikrina maksimalaus suinteresuotumo ginčo baigtimi ir palieka spragą korupcinei įtakai. Be to, nors konkrečių valstybès tarnautojų skyrimui nagrinėti ginčus ir nustatyti apribojimai, siekiant išvengti interesų konflikto, vis dèlto - neaptartas būtent galimų ginčus nagrinèti skirti tarnautojų nepriklausomumas, jų papildomos finansinès garantijos, profesinès veiklos apribojimai ir finansinè parama baigus tarnybą. Lyginant valstybės tarnautojo statusą su teisèjo statusu vienodas nepriklausomumo vertinimas negalimas, jei valstybės tarnautojui specialiais įstatymais nesuteikiamos analogiškos ar atitinkamos nepriklausomumo garantijos. Vis dèlto, nors ir nenustatyta tam tikrų ginčus nagrinėjančių valstybės tarnautojų ir tarybos narių nepriklausomumo užtikrinančių priemonių, tiek pati institucija, tiek jos nariai gali būti vertinami kaip nepriklausomi tiek institucijos sudarymo, tiek atskaitomybès, veiklos kontrolès, sprendimų prièmimo nepriklausomumo atžvilgiais. Be to, aiškiai reglamentuotas tiek pačios Ryšių reguliavimo tarnybos kaip privalomos ginčo nagrinëjimo institucijos privalomumas, tiek jos priimtų sprendimų vykdymo privalomumas. Taip pat aiški priimamų sprendimų vieta teisminiame ginčų nagrinėjime, sureguliuota jų prièmimo ar atmetimo, nagrinėjimo, sprendimų prièmimo ir vykdymo tvarka, kuri daugeliu aspektų yra analogiška civilinių bylų nagrinèjimo tvarkai. Šalims užtikrintos visos procesinès teisès, kas garantuoja inter partes procedūrą, taigi galima pagrịstai daryti išvadą, kad Ryšių reguliavimo tarnybos priimami sprendimai dẻl ginčų yra teisinio nagrinèjimo da- 
lis, o ši institucija gali būti laikoma vykdančia teisingumą. Taigi nors institucijos valdymo organų narių bei ginčus nagrinėjančių narių kvalifikacija nėra aptarta ir nėra aišku, ar besikreipdami ị ESTT institucijos nariai privalo ir/ar gali tureti teisinị išsilavinimą, vis dèlto šis kriterijus laikytinas formaliu ir tai, kad tenkinami visi anksčiau aptarti esminiai kriterijai, leidžia daryti prielaidą, kad Ryšių reguliavimo tarnyba gali būti pripažinta „teismu“ pagal SESV 267 straipsnị.

\section{Išvados ir pasiūlymai}

\section{Išvados}

1. Tam, kad Europos Sajungos Teisingumo Teismas priimtu prejudicinio sprendimo prašymą iš institucijos, turi būti igyvendintos tam tikros sąlygos: besikreipianti institucija ESTT turi būti ịvardijama kaip „teismas“ pagal SESV 267 straipsnị. Dar 1966 m. Vaassen-Göbbels byloje Teismas apibrěžè penkis kriterijus, kuriais galëjo remtis nustatydamas, ar institucija gali būti laikoma „teismu“, o būtent: ar institucija, ikurta teisès aktu pagrindu, ar ji yra nuolatinè, ar ji taiko teisės normas, ar jos jurisdikcija yra privaloma, ar jos procesas grindžiamas rungimosi principu. Po šio sprendimo ESTT vèlesnèse bylose šiuos kriterijus tobulino ir pridejo kitų. Nuo $1997 \mathrm{~m}$. Teismas, prièmęs sprendimą Dorsch Consult byloje, pradèjo vartoti formuluotę ,siekiant nustatyti, ar institucija, kuri kreipiasi dèl prejudicinio sprendimo, turi „teismo“ statusą pagal EB sutarties 234 straipsni (dabar SESV 267 straipsnis), reikia vadovautis tokiais kriterijais: isteigta teisès aktais, nuolatine veikla, proceso metu sprendžiamas ginčas, taiko teisès aktus ir yra nepriklausoma". Nors Teismas tiesiogiai nenurodè, kad tai yra baigtinis kriterijų, leidžiančių nustatyti „teismo“ statusą, sąrašas, tačiau juo vẻliau rèmėsi tiek pats Teismas, tiek generaliniai advokatai.

2. Teismui palikta teisè spręsti, ar tam tikra valstybės narės institucija yra „teismas" nagrinejamo 267 straipsnio tikslais; tam tikros institucijos priskyrimas prie teismų pagal nacionalinius teisès aktus dar nėra galutinis, nes paskutinị žodį taria ESTT. Nuodugniai išnagrinèjus Teismo praktiką matyti, kad Teismas palaipsniui išplètė institucijų, kurioms leidžiama kreiptis prejudicinio sprendimo, ratą ir kurios yra laikomos administravimo ar priežiūros institucijomis, o ne teismais pagal nacionalinę teisę, bet besikreipianti institucija privalo veikti kaip „teismas“ ir ji turi vykdyti teismines galias.

3. Susiaurinus institucijų, galinčių kreiptis prejudicinio sprendimo, ratą, tam tikros institucijos gali likti be ES teisès aiškinimo. Ši pasekmè nèra pageidautina ES požiūriu, ir tai yra vienas iš stipriausių argumentų dèl plataus „teismo“ savokos pagal SESV 267 straipsnị traktavimo.

Kitas argumentas yra tas, kad pasitelkus prejudicinio sprendimo prièmimo procedūrą galima stebèti valstybès narių ịsipareigojimus Europos Sajungai, o šiai veiksmingai kontroliuojančiai priemonei būtu pakenkta apribojant galimybę teikti prašymą priimti prejudicinị sprendimą. 
Taigi, ESTT yra labai lankstus išaiškinant, kas yra „teismas“ pagal SESV 267 straipsnị. Tačiau tai nebūtinai turi turi būti neigiamas pokytis. Nors teismo praktika, atrodo, šiek tiek nenuosekli ir suteikia pagrindo diskusijoms, reikia nepamiršti, kad Teismas iš tiesų bando padaryti prejudicinio sprendimo prièmimo procedūrą prieinamą visoms institucijom, kurioms kyla klausimų dèl ES teisès.

4. Autorès nuomone, prejudicinio sprendimo procedūra turi būti lanksti ne tik dèl vis didejjančio valstybių narių skaičiaus, bet ir to suponuoto dar stipresnio poreikio užtikrinti, kad ES teisè būtų vienodai taikoma ir aiškinama visose Sajungoje. Todèl nèra sunku ịsivaizduoti rezultatą, jei kiekvienas nacionalinis teismas galètu aiškinti ES teisę kaip jam patinka: visa ES kūrimo prasmè ir pagrindas dingtų, nes skirtingų nacionalinių interpretacijų galutinis rezultatas būtų ne kas kita negu 28 skirtingų teisės sistemų derinimas su ES teise vien tik nustatant sistemą, bet ne privalomą pobūdį. Taigi, nacionalinèms institucijoms reikètų ir net jos turètų siekti ES TT išaiškinimų, todèl kuo daugiau institucijų turètų turèti galimybę kreiptis į ESTT.

\section{Pasiūlymai}

Vertinant kompleksiškai išnagrinètus kriterijus, kuriuos atitinka Ryšių reguliavimo tarnyba, siūlytini pakeitimai grynai formalūs, ir jų iggvendinimas tik palengvintų nagrinèjimo dèl institucijos tinkamumo kreiptis dèl prejudicinio sprendimo procedūrą ir labiau užtikrintų sėkmę, kad Ryšių reguliavimo tarnyba būtu pripažinta „teismu“ pagal SESV 267 straipsnị. Taigi, siekiant labiau užtikrinti nepriklausomumo kriterijaus visišką tenkinimą, siūlytina aiškiai institucijos struktūroje suformuoti atskirą ginčų nagrinèjimo skyrių ar padalinį, kurio darbuotojams būtų keliamas tiek teisinio išsilavinimo ir tinkamos kvalifikacijos reikalavimas, tiek taikomi asmenini ginčus nagrinejjančių darbuotoju nepriklausomumą užtikrinantys ịrankiai, aiškiai sureguliuotas jų darbo apmokejjimas, nustatyti kitos veiklos tiek tarnybos metu, tiek tam tikrą laikotarpi po jos apribojimai; arba ginčų nagrinejjimo taisyklèse nustatyti aiškius reikalavimus valstybès tarnautojams, kurie gali būti skiriami nagrinèti ginčus, o Elektroninių ryšių įstatyme kompleksiškai sureguliuotas tokių asmenų nepriklausomumo užtikrinimas ir minèti ịrankiai. Be to, turi būti aptartos ne tik Tarnybos direktoriaus ir tarybos narių atleidimo iš pareigų sąlygos, bet ir būtent tų asmenų, kurie skiriami nagrinèti ginčus. Tokių asmenų statusą taikant nepriklausomumo ịrankius siūlytina orientuoti ị teisejjų statusą.

\section{Literatūra}

Bergères, M.-C. Contentieux communautaire. PUF, $3^{\text {ème }}$ éd., 1998.

Byla C-407/98 Abrahamsson ir Anderson [2000] ECR I-5539.

Byla 14/86 Pretore di Salò [1987] ECR 2545.

Byla 24/92 Corbiau v. Administration des Contributions [1993] ECR I-1277.
Byla 244/80 Pasquale Foglia v. Mariella Novello [1981] ECR 3045.

Byla 246/80 Broekmeulen [1981] ECR 2311.

Byla 61/65 Vaasen-Göbbels [1966] ECR 261.

Byla C-103/97 Josef Köllensperger GmbH\&Co.

$K G$ and Atzwanger AG v. Gemeindeverband 
Bezirkskrankenhaus Schwaz [1999] ECR I-55.

Byla C-24/92 Corbiau [1993] ECR I-1277.

Byla C-258/97 HI [1999] ECR I-1405 ir byla C-275/98 Unitron Scandinavia et 3-S [1999] ECR I-8291.

Byla C-259/04 Elizabeth FLorence Emanuel v. Continental Shelf [2006] ECR I-3089.

Byla C-309/96 Daniele Annibaldi v. Sindaco del Comune di Guidonia and Prezidente Regione Lazio [1997] ECR I-7493.

Byla C-321/97 Andersson and WåkeråsAndersson [1999] ECR I-3551.

Byla C-385/09 Nidera Handelscompagnie [2010] ECR I-10385.

Byla C-516/99 Walter Schmid [2002] ECR $\mathrm{I}-4573$.

Byla C-54/96 Dorsch Consult [1997] ECR I-4961.

Brown, L. Neville; Kennedy, T. The Court of Justice of the European Communities. London: Sweet \& Maxwell , 1994.

Deviatnikovaite, I. Nepriklausomos reguliavimo institucijos valstybinio administravimo instituciju sistemoje. Daktaro disertacija. Socialiniai mokslai (teisè). Vilnius: Mykolo Romerio universitetas, 2012.

Europos Parlamento ir Tarybos 2009 m. lapkričio 25 d. direktyva 2009/140/EB, iš dalies keičianti Direktyvą 2002/21/EB dèl elektroninių ryšių tinklų ir paslaugų bendrosios reguliavimo sistemos, Direktyvą 2002/19/ EB dèl elektroninių ryšiu tinklų ir susijusių priemonių sujungimo ir prieigos prie jų ir Direktyvą 2002/20/EB dèl elektroninių ryšių tinklų ir paslaugų leidimo. [2009] OL, L $337 / 37$.

Generalinio advokato General Ruiz-Jarabo Colomer nuomonè byloje C-17/00 De Coster [2001] ECR I-9445.

Lietuvos Respublikos civiliniu kodeksas. Valstybès žinios. 2000, Nr. 74-2262.

Lietuvos Respublikos elektroninių ryšių ịstatymas. Valstybès žinios. 2004, Nr. 69-2382.

Lietuvos Respublikos Konstitucija. Valstybès žinios. 1992, Nr. 31-953.
Lietuvos Respublikos pašto įstatymas. Valstybès žinios. 1999, Nr. 36-1070; 2012, Nr. 135-6867.

Lietuvos Respublikos Prezidento 2007 m. rugpjūčio 3 d. dekretas Nr. 1K-1077 „Dèl Ryšių reguliavimo tarnybos tarybos narių skyrimo“. Valstybès žinios. 2007, Nr. 88-3486.

Lietuvos Respublikos ryšių reguliavimo tarnybos direktoriaus $2011 \mathrm{~m}$. spalio $21 \mathrm{~d}$. issakymu Nr. 1V-1015 patvirtintos galutinių paslaugų gavejjų ginču su elektroninių ryšiu paslaugų tiekejjais ir ginčų tarp pašto ir(ar) pasiuntinių paslaugų tiekejų ir naudotojų nagrinėjimo taisyklès. Valstybės žinios. 2011, Nr. 130-6176.

Lietuvos Respublikos telekomunikacijų įstatymas. Valstybès žinios. 1998, Nr. 56-1548.

Lietuvos Respublikos Valstybès politikų, teisèjų ir valstybès pareigūnų darbo apmokẻjimo i̊statymas. Valstybès žinios. 2000, Nr. 752271.

Lietuvos Respublikos viešųjų ir privačių interesų derinimo valstybinèje tarnyboje įstatymas. Valstybès žinios. 1997, Nr. 67-1659; 2000, Nr. 18-431.

Lietuvos Respublikos Vyriausybès nutarimas dèl Lietuvos Respublikos ryšiu reguliavimo tarnybos nuostatų patvirtinimo. Valstybès žinios. 2004, Nr. 131-4734.

Norkus, R.; Prapiestytè, D.; Valančius, V. Procesas Europos Bendriju Teisingumo Teisme: preliminarus nutarimas. Vilnius: VI Teisinès informacijos centras, 2004.

Prapiestytè, D. Prejudicinio sprendimo priemimo Europos Sajungos Teisingumo Teisme proceso aiškumas kaip vienodo Europos Sajungos teisès aiškinimo ir taikymo garantija. Daktaro disertacija. Socialiniai mokslai (teisè). Vilnius: Vilniaus universitetas, 2012.

Teisingumo Teismo $2012 \mathrm{~m}$. metinis pranešimas [interaktyvus]. Liuksemburgas, 2012 [žiūrèta 2013-09-09]. <http://curia. europa.eu/jcms/upload/docs/application/ pdf/201304/192685_2012_6020_cdj_ ra_2012_en_proof_01.pdf>. 
Anotacija. Straipsnyje analizuojama prejudiciniu sprendimu augimo tendencijos ir teismu teise kreiptis i Europos Sajungos Teisingumo Teisma del prejudicinio sprendimo. Aptariama "teismo" squvoka ir kriterijai, apibüdinantys institucijas, galinčias tapti prejudicinio sprendimo procedūros subjektais. Daug demesio skiriama įvertinti Lietuvos Respublikos ryšiu reguliavimo tarnybos galimybes pasinaudoti Sutarties dèl Europos Sajungos veikimo (SESV) 267 straipsnyje numatyta procedüra.

Reikšminiai žodžiai: prejudicinis sprendimas, Ryšiu reguliavimo tarnyba, SESV 267 straipsnis, „valstybès nares teismo" squvoka.

\title{
CAN THE COMMUNICATIONS REGULATORY AUTHORITY OF THE REPUBLIC OF LITHUANIA BE RECOGNIZED AS A COURT UNDER ARTICLE 267 OF THE TFEU?
}

\section{Eglè Kybartienè}

\author{
Mykolas Romeris University, Vilnius
}

Summary. The Republic of Lithuania counts the nine years of membership in the European Union. It is clear that Lithuanian courts, which are part of EU judicial system, and other institutions are facing the need to apply for a preliminary ruling.

The European Court of Justice gives a preliminary ruling only if the requesting authority can be recognized as a "court or tribunal" under Article 267 of the TFEU. Which Lithuanian authorities may seek for a preliminary ruling? To answer this question, it is necessary to look at the jurisprudence of the Court, because the Treaty does not provide any clear definition.

The first decision, in which the Court issued an opinion what is the national court and what criteria it must meet, was decision in the Vaassen - Goebbels case (in 1966).

The Court has defined five criteria, which may have been used to determine whether a body can be considered a "court". These criteria are the following: whether the authority was established according to the law, is it permanent, whether it applies rules of law, is the jurisdiction of authority compulsory and using the procedure of inter partes. On the subsequent cases, the Court improved these criteria and added the others. On the judgment of Dorsch Consult case (in 1997), the Court decided the folowing: "to determine whether the institution applying for a preliminary ruling is corresponding "the court" status under Article 234 (now Article 267 - author's note), one must be guided by the following criteria: institution must be established by legislation, has regular activities, the process of the dispute, similar legislation and must be independent".

Each EU Member State, as well as Lithuania, has various state institutions dealing with legal disputes, one of these is the Lithuanian Communications Regulatory Authority. This institution meets the criteria provided by the Court, so it can be assumed that the institution can be treated as a "court" under Article 267. The author believes that the preliminary ruling procedure should be flexible, not only because of the increasing number of Member States, but also because of the growing need to ensure the uniform application and interpretation of $E U$ 
law. National authorities should seek guidance from the Court, and more institutions should be able to apply to the Court for the preliminary ruling.

Keywords: preliminary ruling, the Communications Regulatory Authority of the Republic of Lithuania (RRT), Article 267 of the Treaty, court or tribunal of a Member State.

Eglė Kybartienė, Mykolo Romerio universiteto Teisès fakulteto Tarptautinès ir Europos Sajungos teisès instituto doktorantė. Mokslinių tyrimų kryptys: Europos Sajungos Teisingumo Teismas ir institucijos, galinčios kreiptis ị jị, vartotojų teisių apsauga.

Eglė Kybartienė, Mykolas Romeris University, Faculty of Law, Institute of International and European Union Law, Doctoral student. Research interests: Court of Justice of the European Union and the bodies that can apply to it, consumer protection. 